\title{
Social security and pension arrangements for workers posted abroad and their employers
}

Received (in revised form): 4th March, 2002

\section{Bill Birmingham}

graduated from the University of Manchester, and worked for 25 years in the Department of Social Security, initially in a local social security office dealing with claims to means-tested benefits, but mainly in the fields of occupational pensions policy and the application of European Community legislation in the social security and pensions field. He was subsequently Manager of Benefit Services and Head of Research for the National Association of Pension Funds. He has participated in projects to advise the Governments of Russia, Kyrgyzstan, Hungary and China in the field of pension development and regulation and has been involved in the development of international pensions training. He is now a consultant with the actuarial firm, Lane Clark and Peacock.

\begin{abstract}
This paper examines the statutory provisions and equivalent in the field of social security and occupational pensions applicable to workers seconded by their employer to work abroad. It looks at UK regulations that specify the circumstances under which individuals and employers are liable, or entitled, to pay National Insurance contributions while absent from the UK, and those in which state pensions and other social security benefits are payable while persons are abroad. It also outlines provisions of European Union (EU) Regulations that override UK national provisions for EU and European Economic Area (EEA) nationals absent from the UK in other EU and EEA states. The paper also examines the rules laid down by the Inland Revenue to enable persons working abroad to continue membership of UK occupational, personal and stakeholder pension schemes and to transfer pension rights to foreign schemes. It refers to the EU Directive concerning the protection of supplementary pension rights for persons who move between member states. Although the paper mentions bilateral conventions between the UK and non-EEA states, it does not examine the provisions of each convention.
\end{abstract}

Keywords: European Union Regulations on social security for migrant workers; European Union Directive on pensions for seconded workers; indexation and non-indexation of pension rights abroad; tax treatment of pension scheme membership abroad; temporary absence from the UK

Bill Birmingham Lane Clark \& Peacock, 30 Old Burlington Street, London W1X 2NN, UK.

Tel: +44 (0)1753 544831; e-mail: wbirmi5995@aol.com

\section{The UK Social Security regime and persons abroad}

The Social Security Contributions and Benefits Act 1992 enacts a system of contributions and benefits which essentially presupposes that all contributors and beneficiaries are in Great Britain. ${ }^{1}$ However, the Act recognises that not all workers and beneficiaries remain continuously in the UK. It therefore includes regulation-making powers to require, or entitle, persons abroad and their employers to pay national insurance contributions $^{2}$ and to enable beneficiaries abroad to avoid disqualification for receipt of benefits. $^{3}$ 


\section{Residence and presence conditions for National Insurance contribution liability}

Section 1(6) of the Social Security Contributions and Benefits Act 1992 provides that anyone who does not meet statutory conditions relating to residence and presence in Great Britain is not liable to pay Class 1, Class 1A, Class $1 \mathrm{~B}$ or Class 2 national insurance contributions. ${ }^{4}$ It also provides that, unless permitted by regulations to do so, where someone is not liable to pay such contributions, there is no entitlement to pay contributions either. Similarly, unless a person satisfies the residence and presence conditions, he or she is not entitled to pay the voluntary Class $3^{5}$ contributions. Section 17 of the Social Security Contributions and Benefits Act permits regulations to except from liability for Class $4^{6}$ contributions persons who do not satisfy conditions as to residence and presence in the UK.

When, therefore, are persons treated as satisfying the statutory conditions regarding residence and presence in the UK so that they are liable, and entitled, to pay National Insurance contributions?

The conditions for liability and entitlement to pay primary Class 1 contributions (the employed earner's element of the Class 1 contribution) are that at the time of the employment the employed earner:

— is resident in the UK, or

- is present in the UK, or

- would be present in the UK but for a temporary absence, or

— is ordinarily resident in the UK.

The conditions for liability to pay secondary Class 1 contributions (the employer's element of the Class 1 contribution) or Class $1 \mathrm{~A}$ or Class $1 \mathrm{~B}$ contributions, are that the employer, ${ }^{7}$ who, but for the need to satisfy the residence and presence conditions, would be liable for such contributions:

- is resident in the UK when the contributions become payable, or

- is present in the UK when the contributions become payable, or

- has a place of business in the UK when the contributions become payable,

but an employer may voluntarily pay the contributions, even if not otherwise liable.

The conditions for liability and entitlement to pay Class 2 contributions are that the self-employed earner:

- is present in the UK in a week for which a contribution is due, or

- is ordinarily resident in the UK during a period when the contributions are payable, or

- if not ordinarily resident in the UK, has been resident in the UK for at least 26 weeks out of the 52 weeks before a period in respect of which the contributions are payable.

The conditions for entitlement to pay Class 3 contributions are that the person wishing to pay:

— is resident in the UK throughout the relevant tax year, or

- arrived in the UK during the tax year and became liable to pay Class 1 or Class 2 contributions at an earlier period in that tax year, or

- arrived in the UK during the tax year and was either ordinarily resident in the UK throughout the tax year or became ordinarily resident during the course of the tax year, or

- is not ordinarily resident in the UK, but arrived in the current or previous tax year and has been continuously 
present in the UK for 26 complete contribution weeks.

However, there is an exception ${ }^{8}$ where a person who is not ordinarily resident, nor ordinarily employed, in the UK is employed for a time in the UK as part of an employment which is mainly abroad for an employer with a place of business abroad. ${ }^{9}$ In such cases no primary or secondary Class 1 or Class 1A contributions are payable in respect of the employee's earnings or of a benefit in kind to the employee, ${ }^{10}$ nor will there be any liability for Class 1B contributions until the employee has been resident in the UK continuously for 52 weeks from his last date of entry to the UK.

\section{Payment of National Insurance contributions abroad}

In what circumstances does UK national legislation ${ }^{11}$ enable, or require, workers and their employers to continue to contribute to the UK social security scheme if they go abroad? ${ }^{12}$

If an earner is employed abroad in circumstances in which, had the employment been in the UK, it would have been employed earner's employment, ie with a consequential liability for Class 1 contributions, earnings from the foreign employment may give rise to Class 1 contribution liability for a limited period. Liability in such circumstances arises only if each of the following conditions are satisfied:

— the employer has a place of business in the UK

- the earner is ordinarily resident in the UK; and

- immediately before the employment started the earner was resident in the UK.
In such cases primary and secondary Class 1, Class 1A and Class 1B contributions are payable in respect of the earnings for the foreign employment during the 52 weeks from the start of the week in which the foreign employment began, as though the employment had been in the UK. Where there is, or has been, Class 1 contribution liability in respect of the foreign employment, the earner may pay Class 3 contributions ${ }^{13}$ for any year during which he or she is abroad, including the year when the foreign employment started and the year of return to the UK.

Self-employed earners abroad remain liable for Class 4 contributions on their profits and gains, unless they are treated for income tax purposes as not resident in the UK in the year of assessment.

Where no liability for Class 1 contributions arises in respect of foreign employment, persons abroad may choose to pay National Insurance contributions provided that:

- the person has been resident in the UK for a continuous period of at least three years before the period abroad for which the person wishes to pay the contributions; and

- contributions with an earnings factor of 52 times the year's lower earnings limit (LEL) have been paid by, or on behalf of, the person for each of three years ending before that period. ${ }^{14}$

Where the conditions are satisfied,${ }^{15}$ the earner may pay:

- Class 2 contributions for any contribution week throughout which he or she is gainfully employed abroad $^{16}$ in employment for which there is no Class 1 contribution liability, if, immediately before last leaving the UK, he or she was 
ordinarily an employed or self-employed earner; or

- Class 3 contributions in respect of any year during which he is abroad.

\section{Application of EU Regulations to social security contributions for workers abroad}

Notwithstanding the provisions of the UK Contributions Regulations regarding liability for, and entitlement to pay, National Insurance contributions while working or otherwise abroad, where the EU Regulations ${ }^{17}$ on social security for migrant workers apply, they override those provisions. The Regulations apply only to employed or self-employed persons $^{18}$ who are nationals of EU member states ${ }^{19}$ and of other EEA states ${ }^{20}$ and to refugees and stateless persons residing in an EU or EEA state. ${ }^{21}$ Thus, non-EEA nationals, eg citizens of the USA, Canada or Australia, even if employed by a British employer and seconded to work in another EU or EEA state, are not covered by the Regulations and would remain subject to the UK Contributions Regulations.

The basic principle of the contribution provisions of Regulation 1408/71 is that persons covered by the Regulation should be subject to the legislation of only one state. Accordingly, they and their employer should not be liable to pay social security contributions to the social security institution of more than one state. Thus, although there may be liability for Class 1 national insurance contributions under UK Contributions Regulations for the first 52 weeks of employment overseas, Regulation 1408/71 would preclude a simultaneous liability under that provision and under French legislation for someone seconded by a UK employer to work in France. The corollary of the principle is that those covered by the Regulation are entitled to contribute to the social security institution of at least one EU or other EEA state. They cannot be denied the opportunity, or they and their employers avoid the liability, to contribute after leaving one state because of a condition in another requiring a period to elapse before contributions become payable.

Subject to certain exceptions outlined below, the principle means ${ }^{22}$ that:

- a person employed in an EU or EEA state is subject to the social security legislation of that state, and so liable for contributions under that state's legislation, even if that person resides in another EU or EEA state or the employer's registered office or place of business is in another such state. - a person self-employed in an EU or EEA state is subject to the social security legislation of that state, and so liable for contributions under that state's legislation, even if he or she resides in another such state.

Accordingly, unless covered by an exception, a person seconded by a British employer to work in France, would become subject to French social security legislation and would, with the employer, be liable for French social security contributions, but not British, even where UK legislation would otherwise impose liability.

There are two main exceptions to the principle of being subject to the legislation of the state where the person works. The first exception covers short-term secondments or self-employment abroad. This is primarily to avoid undue administrative complications for both employers and social security institutions due to the need to amend payroll systems and record contribution payments for insignificant periods. 
Where an employee who normally works in one state, eg the UK, is posted by his employer to perform work for the employer in another state, eg, the Netherlands, and the work is expected to last for not more than 12 months, that employee will remain subject to the social security legislation of the first state, in this example, the UK. (This exception does not apply, however, if the employee is sent to replace another employee who has completed his posting.) This would mean that, in the example, the employer and employee would continue to be liable for British, and not Dutch, national insurance contributions while working in the Netherlands, even if under UK Contributions Regulations there was no liability. If, due to unforeseeable circumstances, the work lasted longer than 12 months, the legislation of the employee's home state could continue to apply, provided that the social security institution of the state to which the employee had been seconded had agreed before the 12 months had ended.

However, an extension cannot exceed a further 12 months. A 12-month extension would mean that liability for Class 1 national insurance contributions would continue for longer than the 12 months maximum under UK Regulations alone.

There is an equivalent provision for self-employed workers. Where a self-employed person who normally works in one state, eg the UK, performs work in another state, eg Spain, which is expected to last for not more than 12 months, that person will remain subject to the social security legislation of the first state, in this example the UK. This means that, in the example, he or she would continue to pay British, and not Spanish, national insurance contributions, while working in Spain. If, due to unforeseeable circumstances, the work lasted longer than 12 months, the legislation of the employee's home state could continue to apply, provided that the social security institution of the state to which the employee had gone to perform the work had agreed before the 12 months had ended. However, an extension cannot exceed a further 12 months.

The second major exception arises where the social security institutions of two EU or EEA states agree to provide exceptions to the normal provisions regarding the state to whose legislation an employee or self-employed person is subject. Such agreements (Article 17

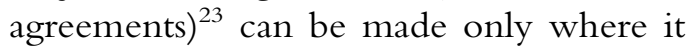
is in the interest of individuals or groups of people concerned. It is not uncommon for such agreements to be made for small groups of seconded workers, but some states, eg Belgium, have been less willing to agree to such arrangements than others. Where an agreement is made, a British worker posted to another state will remain subject to UK national insurance and he or she and the employer will remain liable for Class 1 contributions throughout the secondment. An Article 17 agreement can avoid the complication of an employer being required to set up arrangements to pay contributions in respect of one or a few seconded workers to a foreign social security institution. It also means that the worker is likely to obtain a pension from a single social security institution.

Nevertheless, it could also mean that the worker might in some cases ultimately become entitled to a lower state pension from the UK than would have accrued in aggregate under the legislations of both the UK and the state to which he or she was seconded. Those UK employers wishing their seconded workers to be covered by Article 17 agreements should contact the National Insurance Contributions Office of the 
Inland Revenue to ask them to approach the equivalent body in the other state. Article 17 agreements may sometimes be backdated, particularly where neither social security institution was aware of the foreign employment.

Special provision applies where a worker is employed or self-employed simultaneously in more than one EU or EEA state. Such an employee ${ }^{24}$ is subject to the legislation of:

- the state where he or she resides if either some of the work takes place there, or the employee works for several employers with their registered offices or place of business in more than one state; or

- the state where his employer has its registered office or place of business if he does not reside in any of the states where he or she works.

Self-employed persons who normally work in more than one state are subject to the legislation of the state where they reside, unless they do not work there. In that case, they are subject to the legislation of the state where their main activity takes place.

Even though employees and self-employed persons are under Regulation $1408 / 71$ subject only to the legislation of one EU or EEA state, they may voluntarily contribute to the social security scheme of another state to satisfy the contribution conditions for invalidity, old age and death (widow's and widower's) benefits, provided that the second state's legislation permits the overlapping. Thus, a worker posted by a British employer to work in Germany would become subject to German social security legislation, unless covered by one of the exceptions. However, he or she could additionally pay British Class 2 or Class 3 national insurance contributions voluntarily, provided that the conditions for paying such contributions under the UK

Contributions Regulations were satisfied.

Whether the worker would choose to do so would depend on whether and, if so, how much, additional UK state retirement pension or bereavement benefit would accrue (see below).

\section{Payment of UK state social security benefits abroad}

In the same way as provisions under UK Contributions Regulations are overridden by EU Regulations in relation to persons covered, so UK benefits provisions are similarly overridden, where they apply.

The statutory principle under UK national legislation is that, except where regulations provide otherwise, persons abroad are disqualified for receiving social security benefits and increases of benefit for a beneficiary's spouse are not payable if the spouse is abroad. Similarly child benefit is not payable, unless regulations permit, where the child is abroad, nor to a beneficiary absent from the UK.

\section{State retirement pension and widow's and bereavement benefits abroad}

Notwithstanding the general statutory disqualification on receipt of benefit abroad, the disqualification is lifted in respect of state retirement pension ${ }^{25}$ and widow's and bereavement benefits, but with certain limits:

- where, following an Uprating Order, regulations are made to provide that the disqualification should not be lifted in respect of the uprating increase, the disqualification continues to apply in respect of the increase for persons ordinarily resident abroad. Accordingly their entitlement is frozen at the rate payable when the 
pension or benefit was awarded or at the rate payable when they ceased to be ordinarily resident in the UK. This has the effect that pensioners ordinarily resident in, for instance, Australia do not receive uprating increases, except when they pay a visit to the UK, during which time their pension is paid at the current UK rate. On leaving the UK again, their pension reverts to the rate previously payable in the state where they are ordinarily resident. This contrasts with the position of pensioners covered by EU regulations or certain bilateral Conventions, including with the USA, which provide for pensions and bereavement benefits to be paid at the current UK rate where the pensioner is resident in the state concerned.

- The disqualification for receipt of the lump sum bereavement payment is lifted only if either the deceased or surviving spouse was in the UK when the deceased spouse died, or the survivor returned to the UK within four weeks of the late spouse's death, or the contribution conditions for widowed parent's allowance of bereavement allowance are satisfied. (In practice, very few fail to qualify.)

- Restrictions apply to the lifting of disqualification for the receipt by a surviving spouse or married women of 'inherited SERPS' where the contributor is no longer ordinarily resident in the UK or surviving spouse was not ordinarily resident when the late spouse died.

\section{State incapacity benefits and statutory sick pay abroad}

What happens if someone sent to work abroad or a member of their family is taken ill and is unable to work?

A worker abroad is treated as an employee for the purposes of entitlement to statutory sick pay $(\mathrm{SSP})^{26}$ if:

— the worker works in another EU member state in circumstances in which, had the work been in the UK, he or she would have been an employee for SSP purposes, and is subject to UK legislation under Regulation $1408 / 71 ;{ }^{27}$ or

- the employer is liable to pay secondary Class 1 national insurance contributions in respect of the worker while employed abroad. ${ }^{28}$

Where a person abroad is treated as an employee and is incapable of work in a period of entitlement to SSP during the absence abroad, the SSP entitlement abroad ceases only when entitlement would have ceased in the UK, even if the employer's liability for secondary Class 1 contributions ceases. The SSP Regulations recognise that there may be problems for both the employee and employer in complying with statutory time limits in connection with SSP. Accordingly, they are each deemed to have met the requirements if they have done what is required as soon as practicable.

The disqualification for receipt of social security benefits during absence abroad applies in respect of incapacity benefit, unless the absence is temporary. Where the absence is temporary, the disqualification does not apply if:

- the Secretary of State (or in practice a DWP official on his behalf) has certified that it is consistent with the proper administration of the Social Security Contributions and Benefits Act 1992 that, if one of the conditions below is satisfied, the disqualification should not apply; ${ }^{29}$ and

- the absence is for the specific purpose 
of being treated for incapacity which commenced before the person left the $\mathrm{UK} ;{ }^{30}$ or

- on the day that the absence began the person was, and had for six months continuously been, incapable of work and the incapacity had continued throughout the absence.

This means that under UK national legislation a person who becomes incapable of work while abroad cannot qualify for incapacity benefit until after returning to the UK.

The regulations remove the disqualification in respect for persons abroad for receipt of attendance allowance, disability living allowance and invalid care allowance. However, to be entitled to attendance allowance or disability living allowance a person has to be ordinarily resident in the UK and to be present in the UK and to have been present for 26 weeks out of the last $52 .{ }^{31}$ Temporary absences count as presence if the absence is, and when it began was, for a temporary purpose and has not lasted beyond 26 weeks, or is temporary, for the specific purpose of being treated for incapacity or the disabling condition and the Secretary of State has issued a certificate analogous to the incapacity benefit certificate. Similar requirements apply to invalid care allowance. ${ }^{32}$ Thus, if an employee is seconded to work abroad for other than a short period and has a member of the family entitled to one of these benefits, it is unlikely that the benefit will continue in payment throughout the period abroad.

\section{Increases of state benefits for a spouse abroad}

Disqualification due to a spouse's absence from the UK for receiving in respect of a spouse an increase of benefit that would be payable if the spouse had been in the UK, is lifted if the husband and wife are residing with each other. ${ }^{33}$ The disqualification is lifted whether the beneficiary is in the UK and the spouse abroad, or both are abroad, provided that the beneficiary is not disqualified for receipt of the benefit due to absence from the UK.

\section{Child benefit}

Notwithstanding the provisions under which child benefit is not generally payable to a person abroad, child benefit may be paid for the first eight weeks of a person's absence abroad if: ${ }^{34}$

- the person is entitled to child benefit for the child the week before the first week of the beneficiary's absence; and

- the absence abroad was when it began intended to be temporary and has throughout remained so.

If the child is abroad, child benefit may be paid in respect of the child if:

- someone is entitled to child benefit in respect of the child for the week before the child's absence abroad, the absence was when it began intended to be temporary and has throughout remained so and the week is within the 12 weeks beginning with the first week abroad; or

- is a week in which the child's absence is due to receiving full-time education at an EU or other EEA state educational establishment, or to an educational exchange or visit with the written approval of the child's school or other educational establishment; or

— the child's absence abroad is for the specific purpose of being treated for illness or disability that commenced before the absence began and is in a period falling within the Secretary of State's discretion. 
Persons abroad entitled to a social security benefit may claim an increase for a dependent child, or persons entitled to such a benefit may claim an increase for a child abroad, if they are entitled to child benefit for the child. They may also claim an increase in certain circumstances when child benefit is not payable.

Thus a worker seconded abroad for any lengthy period, or the worker's spouse, is unlikely to be able to draw child benefit under UK national legislation for a child with him, or even for a child remaining in the UK.

However, child benefit would be payable for the child in the UK, for instance, to a spouse remaining behind in the UK.

\section{Acquisition and payment abroad of UK social security benefits under EU Regulations}

Council Regulation (EEC) No. 1408/71 assists EU and EEA nationals and others covered by the Regulation who have worked in more than one EU or EEA state to acquire entitlement to state benefits and pensions, or to a higher rate of such benefits or pensions, than they would acquire under the respective national legislations alone. This enables employees and self-employed mobile workers to acquire title, for instance, to a British retirement pension in circumstances where under UK legislation there would be no entitlement because of insufficient qualifying years.

\section{Payment abroad of UK social security benefits under EU Regulations}

Regulation 1408/71 provides in respect of persons covered by the Regulation that invalidity, old age and survivor's benefits and benefits for accidents at work and occupational diseases are not subject to reduction, withdrawal or modification because the beneficiary resides in, or is in, a state other than that of the paying institution. This means that UK retirement pensions, bereavement benefits and long-term incapacity benefit are payable at the UK rate to persons covered who are resident or present in another EU or EEA state. This overcomes the disqualification under UK national legislation for receiving uprating increases. Similarly, persons who have acquired entitlement to such pensions under the legislation of other EU or EEA states may receive the pensions on in the UK at the rate that would be payable in the state awarding the benefit.

However, this provision does not apply to non-contributory benefits, such as attendance allowance, disability living allowance and invalid care allowance, which are not payable under Regulation $1408 / 71$ in other states. The Regulation does, however, assist the acquisition of such benefits on return to the UK by treating periods in another EU or EEA states as periods of residence in the UK.

\section{Acquisition of state retirement and survivor's benefits under EU Regulations}

A worker who works in more than one EU or EEA state may as a result obtain a lower entitlement to retirement pension, or his widow or her widower to survivor's benefit, under the respective national legislation than if he or she had worked throughout in only one state. Thus, for instance, someone who comes to work and pay national insurance contributions in the UK for five years would fail to satisfy the contribution conditions under UK legislation for entitlement to UK basic state retirement pension even at the lowest reduced rate, as that person would have as qualifying years less than the minimum of 25 per 
cent of years in their working life. The intention of the 'aggregation and apportionment' provisions of Regulation $1408 / 71$ is to overcome this effect for workers whose working life is spent in more than one state.

Under the aggregation and apportionment provisions, a worker who has been a member of the state social security regime of more than one EU or EEA state (or the member's widow or widower) makes a single claim to the social security institution of one such state, generally the state of last employment or alternatively the state where the claimant lives. In making the claim, the claimant provides details of all other states in which he or she has worked, resided and contributed. A copy of the claim is then forwarded on standard forms to the social security institution of each of those states. Each state then provides to each other details of the claimant's insurance record within its jurisdiction, so that each state can calculate entitlement to its own benefit under the Regulation.

A claimant will be entitled to a retirement pension (or survivor's benefit) from each state to whose social security he or she has been subject calculated on the higher of the following two alternatives:

1 Entitlement calculated on the basis of its legislation alone.

2 Entitlement calculated under aggregation and apportionment. Each state aggregates the contribution (or equivalent) records that the claimant has built up under the social security legislation of each state in which he or she has worked. Then they each calculate the rate of pension that would be payable under their own legislation if the aggregate record had arisen in their own state alone. They then each pay the proportion of that notional pension which the period of insurance under their own legislation bears to the aggregate total. Exceptionally, if a worker's insurance period in any state does not amount to at least a year, that state does not have to pay any benefit under the arrangements.

Examples of the application of the arrangements are as follows (in each case the assumption is that the person concerned is an EU or EEA national if not, any entitlement would arise under national legislation alone):

a) A woman works for three years in Ireland and 40 years in the UK. She satisfies the UK contribution conditions for UK basic retirement pension at the full rate, so the UK pension is paid at that full rate. The Irish authorities calculate the entitlement to Irish pension on the basis of 43 years of contributions in Ireland and then pay $3 / 43$ rds of that notional entitlement.

b) A man works for 40 years in Ireland and three years in the UK. The UK authorities calculate the notional entitlement to UK basic retirement pension on the basis of 43 qualifying years, but would then pay $3 / 43$ rds of that entitlement. The Irish pay 40/43rds of the Irish pension entitlement or the full rate, if higher under Irish national legislation.

Notwithstanding that the UK pension rate is lower than the minimum under UK national legislation alone, the pension is still payable at that rate.

c) A man works for 20 years in the UK, 15 years in France and five years in Belgium. The British, French and Belgian authorities would each aggregate the respective records. The UK pays 20/40ths of the notional British entitlement; the French 
15/40ths of the French entitlement and the Belgians 5/40ths of Belgian entitlement.

d) A man works for 20 years in France, 20 years in Germany and nine months in the UK. The French and German authorities aggregate all the periods and respectively pay the French and German entitlement. The British authorities pay nothing because the period of insurance in the UK was less than a year.

e) A woman works for two years in the UK, two years in France and 36 years in Thailand. The UK and French authorities aggregate the British and French records to determine whether there would be any notional entitlement under national legislation on the basis of the aggregation. There is no UK entitlement as, even with the aggregation, there would be no entitlement under UK legislation because the number of qualifying years in the woman's working life would be less than the 25 per cent minimum for entitlement to a UK basic retirement pension.

Where entitlement arises under national legislation alone, that national legislation may include overlapping benefit provisions to reduce entitlement to take account of entitlement arising under the legislation of another state. However, no overlapping reduction may occur in relation to a pension arising as a result of voluntary contributions paid to a second state in addition to the mandatory contributions paid to the social security authority of the state of employment.

When calculating the notional entitlement to SERPS or state second pension (S2P) under UK legislation for the purpose of the aggregation and apportionment provisions, the aggregate surpluses arising under UK legislation are divided by the number of UK tax years since 6th April, 1978 in which they arose. The resulting figure is deemed to be the average throughout.

\section{Acquisition of invalidity benefits under EU Regulations}

Acquisition of invalidity benefits depends on the states to whose legislation the worker has been subject. If the worker has been subject only to the legislation of Belgium, Spain (except the scheme for civil servants), France (except the special scheme for miners), Greece (only the scheme for agricultural workers), Ireland, the Netherlands, and the UK, the state in which the incapacity arose will provide invalidity benefit (in the UK, long-term incapacity benefit) in accordance with its own legislation and nothing will be paid by any other state. If, however, the worker has at any time been subject to the legislation of Denmark, Germany, the Spanish civil service scheme, the French miners scheme, Greece (other than for agricultural workers), Italy, Luxembourg, Austria, Portugal, Finland or Sweden, the aggregation and apportionment provisions apply as for retirement pension. In such cases the aggregation and apportionment provisions apply to the invalidity benefit legislation of all states to which the worker has been subject, not just of those whose legislation causes those provisions to apply.

\section{Entitlement to family benefits under EU Regulations}

An employed or self-employed person subject to the legislation of an EU or EEA state is entitled to the family benefits (in the UK, child benefit) in respect of children residing in another state as if they were residing in that state. Where as a result there would be entitlement to family benefits under the 
legislation of more than one state, the state, other than that in which the worker works, may suspend payment of its benefit, but where its benefit rate is higher than the rate awarded in the state where the worker is employed or self-employed, it must pay a supplement of the difference.

\section{Bilateral agreements}

The social security system in Great Britain and Northern Ireland operates on a reciprocal basis with an analogous scheme in the Isle of Man. There is a reciprocal agreement with Jersey and Guernsey, whose social security arrangements are different from those of the UK and from those of each other.

The reciprocal agreement between the UK and Gibraltar provides that Regulations (EEC) Nos. 1408/71 and $574 / 72$ apply as though the UK and Gibraltar were separate EU states.

In addition to all EU and EEA states, the UK has concluded bilateral conventions with the following states: Australia, Barbados, Canada, Cyprus, Israel, Jamaica, Japan, South Korea, Malta, Mauritius, New Zealand, Philippines, Switzerland, Turkey, USA and Yugoslavia (which covers all successor states to the former Yugoslavia). Although many of them have similar provisions, there are a number of major differences. Some, for instance, lift the disqualification for uprating increases of state retirement pension; others do not. If, therefore, a worker goes to work in one of these states, it will be necessary to examine the particular convention to ascertain what effect it will have on contribution liability and benefit entitlement. Entitlement to UK pensions and other benefits arising under a bilateral convention do not come within the scope of the exportability and aggregation and apportionment provisions of Regulation 1408/71.

There are in addition agreements that the EU has concluded with other states. The Association Agreements with Hungary, Poland and Turkey apply certain provisions of Regulation 1408/71 to mobile workers to and from those states. More limited provisions apply under the Cooperation Agreements with Algeria, Morocco and Tunisia.

\section{Occupational pensions and persons abroad}

The Inland Revenue permits employees working abroad to remain members of UK approved occupational pension schemes in specific circumstances. The conditions are specified in the Inland Revenue's Practice Notes (IR 12).

Employees who work abroad for a UK resident employer may be members of, and accrue benefits under an approved scheme, even if the employees are not chargeable to UK income tax under Case I or II of Schedule E. However, they must have a contract of employment with the UK employer and receive remuneration from the employer.

If the earnings of such an employee are not chargeable under Case I or II of Schedule E, the employee may be provided with benefits, not subject to Inland Revenue limits, under an unapproved scheme without tax liability arising for the employee on employer contributions. However, in such cases tax liability will arise on the benefits if the pensioner is resident in the UK. If such a scheme commutes a proportion of the pension to a lump sum, the Inland Revenue provides an extra-statutory concession giving relief from tax. This applies if at least 75 per cent of the employee's service for the employer was abroad or, if, where the service for the employer exceeds ten years, the last ten 
years were spent abroad, or, where it exceeds 20 years, ten of the last 20 years were abroad.

If an employee is permanently transferred to an overseas employer and the employee's earnings cease to be chargeable under Case I or II of Schedule E, that employee will no longer be eligible to be a member of an approved scheme and must be treated as having left pensionable service. Any benefit entitlement must be restricted to that based on pensionable service while the employee was eligible for membership.

Employees working abroad for an overseas employer may remain members of an approved pension scheme only ${ }^{35}$ in the following circumstances:

- they must have a contract of employment with a UK resident employer and receive remuneration from the employer

- there is a definite expectation that they will return to the UK either to take up employment with a sponsoring employer of the scheme (confirmed in writing) or to retire

- their earnings remain chargeable to UK tax under Case I or II of Schedule E because they work abroad for less than 365 days in any year.

In such cases the UK employer should continue to pay any employer contributions to the approved scheme, but must be reimbursed by the overseas employer at least annually. ${ }^{36}$ The prospective pension for the foreign service should be calculated and funded by reference to the remuneration rate for comparable employment in the UK. The period of service abroad for the overseas employer (ie, excluding any period when the employees performed duties abroad for the UK employer) should be restricted to ten years in aggregate, but aggregation is not needed where the periods of foreign service are separated by at least one year's employment in the UK. There is no requirement for an employee to have worked in the UK before going to work for the overseas employer, provided the conditions above are satisfied.

An employee who is temporarily performing duties abroad may continue to accrue benefits under an approved UK scheme even if he or she becomes a member of an overseas scheme, but, if so, no transfer to the UK approved scheme can be made of rights under the overseas scheme.

Employees temporarily abroad who are not in paid employment or selfemployment while abroad may remain in full membership of an approved scheme for a period of up to ten years if there is a definite expectation that they will return to service with the employer (confirmed in writing) and they have given the employer a written undertaking not to do paid work while abroad. If they do start paid work while abroad, membership must cease, unless the employment is with the same employer, with another sponsoring employer of the scheme, or with an overseas employer on secondment provided that the conditions specified above are met. ${ }^{37}$

Persons working abroad while members of a UK occupational pension scheme and their employers or vice versa may be assisted by a Double Taxation Agreement to avoid duplication of tax liability.

\section{Personal and stakeholder pensions and persons abroad}

A member of a personal or stakeholder pension scheme who is resident abroad may contribute to the scheme during a 
tax year in which he or she has net relevant earnings. ${ }^{38}$

A member of a personal or stakeholder pension scheme who is resident abroad may still contribute to the scheme, even if he or she has no relevant earnings if:

- at some time in the tax year the member was resident or ordinarily resident in the UK; or

- at some time in the past 5 years the member was resident or ordinarily resident in the UK and was resident or ordinarily resident in the UK when he or she joined the scheme. ${ }^{39}$

The maximum level of contributions, if the member is not also accruing benefits under an occupational pension scheme for at least part of the year, is the higher of the earnings threshold ( $\_3,600$ for 2001/02) or the applicable percentage of his net earnings from a chosen basis year. If he or she is accruing occupational pension benefits for the whole of the year, the maximum level of contributions is the earnings threshold. A person with foreign emoluments may join a personal or stakeholder pension scheme, but if they are also a member of a scheme analogous to a UK occupational pension scheme, the maximum level of contributions is the earnings threshold.

A person who has joined a personal or stakeholder pension scheme in the UK must inform the scheme administrator on moving abroad.

\section{EU Directive on safeguarding supplementary pension rights of employed and self-employed persons moving within the EU}

EU Directive 98/49/EC requires member states to take measures to ensure that the vested pension rights of deferred members of supplementary pension schemes, including UK occupational, personal and stakeholder pension schemes, who move to another member state are preserved on the same basis as for those who move within the same state. The existing UK preservation and revaluation provisions comply with this requirement, as they do not restrict their application to those remaining in the UK. Member states must also ensure that employers and scheme trustees and managers supply information about pension rights and choices to deferred members who have moved to another member state at least equal to the information they provide to deferred members in the home state. The British disclosure requirements do not differentiate between UK and foreign resident members.

The Directive also requires member states to ensure that such schemes pay all benefits, net of tax and transaction charges, due under the scheme to members and other beneficiaries where they are in another member state. Accordingly, schemes must pay benefits to their overseas pensioners on the same basis as to their UK resident members.

The Directive requires member states to adopt measures to enable contributions to be paid to a supplementary pension scheme established in the state in respect of a posted worker during the period of the worker's secondment to another member state. In this context a 'posted worker' is a worker who remains subject to the social security legislation of one state while employed in another. ${ }^{40}$ While the posted worker remains a member of a supplementary scheme established in the state from which he or she was posted, the worker and employer are exempt from any requirement to contribute to a supplementary scheme in the state to which the worker was posted. ${ }^{41}$ 


\section{Transfers to overseas schemes or arrangements}

The following provisions apply if a member wishes to transfer pension rights from a UK occupational pension scheme to a foreign scheme. Separate rules (below) apply to the transfer of guaranteed minimum pensions (GMPs), s. $9(2 \mathrm{~B})$ rights and protected rights from contracted-out occupational or appropriate personal pension schemes.

Inland Revenue rules for the transfer of rights (other than contracted-out rights) from a UK occupational pension scheme to a foreign scheme require all the following conditions to be satisfied:

- no part of the benefit of the UK scheme has come into payment, other than income drawdown from an AVC fund

- the transfer is made directly from the UK scheme administrator or trustees to the foreign equivalent in their capacity as administrator or trustees

- the transfer value does not exceed the amount sufficient to meet the maximum approvable benefit for the transferee

- the transfer value does not include a loan from the scheme trustees to a participating employer; and

- the member has a statutory right to a cash equivalent or scheme rules permit a transfer to an overseas scheme.

Where the above conditions and provisions of the reciprocal arrangements are satisfied, a transfer may be made in accordance with reciprocal arrangements to a scheme established in Jersey, Guernsey, the Isle of Man or Ireland. In other cases, including where the reciprocal arrangements do not apply, the following additional conditions must be satisfied (with written confirmation): ${ }^{42}$
- the transferee has left the UK permanently with no intention to return to work or retire

- the transferee is already in employment or self-employment abroad (but not for an overseas branch or representative of a UK resident employer)

- the transferee's UK employment arrangements have been completely severed and the transferee does not exercise self-employment in the UK

- the transferee is resident, and the receiving scheme established, in the same country

- the receiving scheme has (or schemes have) been authorised or recognised by the appropriate or tax authority of the state (states) where it is (they are) established

- the overseas scheme is capable of receiving the transfer. (This excludes pay-as-you-go, unfunded or book reserve arrangements.)

If the above conditions are satisfied, a transfer may be made without the Inland Revenue's consent, provided that the member is neither a controlling director nor a high earner with earnings exceeding the 'earnings cap' in any of the six years before the tax year in which the transfer request is made. If the member is a controlling director or high earner, Inland Revenue's consent must be sought before a transfer can be made.

Comparable requirements apply in respect of a transfer from a personal or stakeholder pension scheme to a foreign scheme. A transfer payment of a member's GMP rights may be made to an overseas scheme if:

- the member consents in writing

- the transferring scheme trustees have taken reasonable steps to satisfy themselves that the member has 
emigrated permanently and is in employment to which the receiving scheme relates

- the amount of the transfer payment is equal to the cash equivalent of the member's GMP rights

- the member has confirmed in writing that he accepts that the receiving scheme is not subject to UK regulation and accordingly there may be no statutory obligation on that scheme to provide a particular value or benefit on receipt of the transfer payment; and

- the transferring scheme trustees have taken reasonable steps to satisfy themselves that the member has received a statement from the receiving scheme showing the benefits to be awarded following the transfer and any conditions under which they could be withheld.

A transfer payment of a member's s. 9(2B) rights may be made to an overseas scheme or arrangement if:

- the member consents in writing

- the transferring scheme trustees have taken reasonable steps to satisfy themselves that the member has emigrated permanently and is in employment to which the receiving scheme relates

- the member has confirmed in writing that he accepts that the receiving scheme is not subject to UK regulation and accordingly there may be no statutory obligation on that scheme to provide a particular value or benefit on receipt of the transfer payment; and

- the transferring scheme trustees have taken reasonable steps to satisfy themselves that the member has received a statement from the receiving scheme showing the benefits to be awarded following the transfer and any conditions under which they could be withheld.

A transfer payment of a member's protected rights may be made from a contracted-out money purchase (COMP) occupational scheme or appropriate personal pension (APP) scheme to an overseas scheme or arrangement if:

- the member consents in writing

- the transferring scheme trustees or managers have taken reasonable steps to satisfy themselves that the member has emigrated permanently and is in employment to which the receiving scheme relates

- the amount of the transfer payment is equal to the cash equivalent of the protected rights to which effect is being given

- the member has confirmed in writing that he accepts that the receiving scheme is not subject to UK regulation and accordingly there may be no statutory obligation on that scheme to provide a particular value or benefit on receipt of the transfer payment; and

- the transferring scheme trustees or managers have taken reasonable steps to satisfy themselves that the member has received a statement from the receiving scheme showing the benefits to be awarded following the transfer and any conditions under which they could be withheld.

\section{References}

1 There are comparable provisions for Northern Ireland under the equivalent Northern Ireland legislation. Reciprocal arrangements allow periods in Northern Ireland to be treated as in Great Britain and vice versa and for the aggregation of contributions paid respectively in Great Britain and Northern Ireland.

2 The Social Security Contributions and Benefits Act 1992, s. 1(6) in respect of Class 1, 1A, 1B, 2 and 3 contributions and s. 17(1) and (2) in respect of Class 4 contributions. 
3 The Social Security Contributions and Benefits Act 1992, s. 119 in respect of National Insurance benefits and s. 146 in relation to child benefit.

4 Earnings-related Class 1 contributions are payable by employed earners and their employers; Class 1A are payable by employers in respect of cars and fuel and certain other benefits in kind provided to their employees; Class 1B are payable where there is a PAYE settlement agreement with the Inland Revenue and Class 2 flat rate contributions payable by self-employed earners.

5 Class 3 flat rate contributions are payable voluntarily to provide or make up entitlement to benefit

6 Class 4 earnings-related contributions payable by self-employed earners on their profits or gains.

7 Or other person liable for such contributions.

8 There are further exceptions in respect of persons not ordinarily resident in the UK who either are engaged in full-time study abroad but work temporarily in the UK under a contract of service during the vacation in work similar or related to their course; or are engaged under a contract of service in the UK in a relationship with a foreign employer analogous to a UK apprenticeship where the employment began before the individual reached age 25 .

9 Even if the employer has a place of business also in the UK.

10 Or to a member of the employee's family.

11 See below where the employee is a national of an EU Member State or EEA state, works in an EU or EEA state and Regulation (EEC) No. 1408/71 applies.

12 There are separate provisions in respect of mariners, airmen, continental shelf workers and volunteer development workers.

13 Provided that the payment is made within the statutory time limit and only to the extent to which the earner could have paid the contribution, had he or she been in the UK.

14 There are alternative provisions where the second condition is not satisfied, but at least 52 flat rate contributions under repealed legislation have been paid for each year for which the three years with earnings factors at 52 times the LEL condition is not satisfied.

15 Provided also that the payment is made within the statutory time limit and only to the extent to which the earner could have paid the contribution, had he or she been in the UK.

16 Any period during the employment abroad when the earner is temporarily in the UK is treated for this purpose as though the earner was still abroad.

17 Regulations (EEC) Nos. 1408/71 and 574/72, as amended, and as extended to EEA states.

18 In this context employed or self-employed persons includes those formerly employed or self-employed, including unemployed people, provided that they have not left the workforce. The precise definition may be found in Regulation 1408/71, Art. 1(a). To a limited extent the Regulation applies also to survivors and members of the family of such people.
19 Austria, Belgium, Denmark, Finland, France, Germany, Greece, Ireland, Italy, Luxembourg, Netherlands, Portugal, Spain, Sweden and the UK.

20 Iceland, Norway and Liechtenstein.

21 The Regulation is extended to apply also in certain circumstances to nationals of non-EEA states, eg Turkey, under Association Agreements.

22 There are separate provisions in relation to mariners (who are generally subject to the legislation of the state whose flag the ship is flying), and to civil servants and members of the armed forces (who are generally subject to the legislation of the state that they are serving).

23 Such agreements are made under Art. 17 of Regulation 1408/71.

24 Different arrangements apply to those engaged in cross-frontier transport undertakings, including by air.

25 Including Category B retirement pensions payable to spouses and widows and widowers, non-contributory Category D pensions payable to persons aged 80 or over, the SERPS or state second pension (S2P) additional pension and graduated retirement benefit. However, the disqualification is not lifted in respect of the $25 p$ a week age addition payable to pensioners over 80 unless the pensioner is ordinarily resident in the UK while abroad, or had been ordinarily resident in the UK and become entitled to the age addition before ceasing to be ordinarily resident in the UK, or is assisted by one of certain bilateral conventions with other states.

26 But if the worker would not have been treated as an employee for SSP purposes, if he or she had been in the UK, the worker is not brought within the definition of employee under the following provisions.

27 The worker abroad would be subject to UK legislation under a 12-month secondment or an Article 17 agreement under Regulation 1408/71 (see above).

28 (See above for the circumstances in which Class 1 contributions are payable in respect of employees working abroad.) (NB. There are separate provisions in respect of mariners, airmen and continental shelf workers.)

29 This condition is imposed to ensure that disqualification is lifted only where the DWP can independently confirm the incapacity. It does not apply if the beneficiary is entitled to attendance allowance or disability living allowance.

30 An alternative version, where the incapacity was caused by an industrial injury, is where the absence is for the specific purpose of receiving treatment appropriate to that injury.

31 The requirement to have been in the UK for 26 out of the last 52 weeks does not apply if the claimant claims on the grounds that he or she is terminally ill.

32 To be treated as present in the UK while abroad the absence must, when it began, have been for a temporary purpose and not lasted more than four weeks or be temporary and for the specific purpose of caring for the disabled person who is also abroad 
and is entitled to attendance allowance or certain components of disability living allowance.

33 Spouses temporarily absent from each other are treated as residing together.

34 If a woman gives birth in the week she leaves the UK or gives birth abroad, the first condition is amended to provide that the woman would have satisfied the conditions for entitlement if the child had been born the week before the woman left the UK.

35 Unless the specific consent of the Inland Revenue is obtained.

36 Reimbursement is not required where the Inland Revenue have agreed otherwise, but they are likely to agree only where reimbursement cannot be made because of exchange control difficulties or statutory prohibitions on transfers of assets to the UK.
37 If the employee is seconded to an overseas employer, the maximum ten years aggregate period abroad includes the unpaid period.

38 Inland Revenue requirements for personal and stakeholder pensions schemes are in Practice Notes IR 76(2000). There are special arrangements for seafarers qualifying for 100 per cent foreign earnings deduction.

39 There is a further alternative for Crown servants serving abroad and their spouses.

40 Under Regulation 1408/71 (see above).

41 See above for Inland Revenue rules about membership of a UK occupational pension scheme while seconded abroad.

42 Different conditions apply for transfers to an EU institution's pension arrangements. 